\title{
Pelatihan TOEFL ITP untuk Mahasiswa Tingkat Akhir Politeknik Ketenagakerjaan
}

\author{
Octovianus Bin Rojak \\ Politeknik Ketenagakerjaan \\ Korespondensi: octovianus@polteknaker.ac.id
}

\begin{abstract}
This activity aims to provide training to final year students of the Polytechnic of Manpower who have never received any training to achieve a minimum TOEFL ITP score of 460. A minimum TOEFL score of 460 is the minimum score for a person to be called an independent user and a requirement to issue a TOEFL ITP certificate with a bronze predicate. The lecture, drill and question and answer methods are used in the process of delivering material in this community service activity. The result of this activity is an output in the form of TOEFL ITP training for Polytechnic of Manpower students. From the results of the training, it can be concluded that this activity achieved its objective, although with some notes that were used as suggestions for this activity. There are four suggestions for improving this activity, namely (1) the duration of the TOEFL ITP training is extended or the number of meetings are increased, (2) the classes are made separately according to the level of the participants, (3) the schedule is adjusted according to the availability of the participants, and (4) the material that has been taught is uploaded to media such as YouTube, so that participants can still access it for self-study.
\end{abstract}

Keywords: drill, lecture, question and answer, TOEFL ITP, training

\begin{abstract}
Abstrak
Kegiatan ini bertujuan memberikan pelatihan kepada mahasiswa tingkat akhir Politeknik Ketenagakerjaan yang belum pernah sama sekali mendapatkan pelatihan untuk mencapai nilai TOEFL ITP minimal 460. Nilai TOEFL minimal 460 merupakan nilai minimal seseorang disebut sebagai pengguna mandiri dan syarat untuk diterbitkan sertifikat TOEFL ITP dengan predikat Bronze. Metode ceramah, drill dan tanya jawab digunakan dalam proses penyampaian materi dalam kegiatan pengabdian kepada masyarakat ini. Hasil dari kegiatan ini merupakan luaran berupa pelatihan TOEFL ITP kepada mahasiswa Politeknik Ketenagakerjaan. Dari hasil pelatihan tersebut, dapat disimpulkan bahwa kegiatan ini mencapai sasarannya meskipun dengan beberapa catatan yang dijadikan sebagai saran bagi kegiatan ini. Terdapat empat saran untuk perbaikan kegiatan ini yaitu (1) durasi pelatihan TOEFL ITP diperpanjang atau jumlah pertemuannya ditambah, (2) kelas dibuat terpisah sesuai level pesertanya, (3) penyusunan jadwal disesuaikan dengan ketersediaan pesertanya, dan (4) materi yang sudah diajarkan diunggah ke media seperti YouTube supaya peserta tetap bisa mengaksesnya untuk pembelajaran pribadi.
\end{abstract}

Kata kunci: ceramah, drill, pelatihan, tanya jawab, TOEFL ITP 


\section{A. Pendahuluan}

Keterampilan bahasa Inggris merupakan kebutuhan yang tidak bisa dinegosiasikan lagi dalam era globalisasi saat ini. Namun, kebutuhan tersebut tidak dibarengi dengan upaya untuk menguasainya. Di Indonesia, khususnya lingkup pendidikan, lembaga legislatif, maupun lembaga-lembaga pemerintahan lainnya, bahasa Inggris hanya dianggap sebagai bahasa asing sehingga status bahasa Inggris tidak menjadi jelas. Hal ini diperburuk dengan diberlakukannya bahasa Inggris hanya sebatas bahasa asing yang wajib dipelajari untuk lulus di dalam ujian bagi para pelajar dari berbagai tingkatan pendidikan, bukan untuk tujuan yang lebih tinggi yaitu berkomunikasi (Salam, 2017).

Penguasaan bahasa Inggris dapat diukur dengan beberapa jenis tes seperti Test of English as a Foreign Language (TOEFL), International English Language Testing System (IELTS), dan Test of English for International Communication (TOEIC). Di antara ketiga tes tersebut, TOEFL merupakan tes bahasa Inggris yang paling lazim di Indonesia (Fitria \& Prastiwi, 2020). TOEFL sendiri terdiri dari dua jenis yaitu TOEFL Internet Based Test (IBT) dan yang lebih lebih lazim yaitu TOEFL Paper Based Test (PBT), yang lebih dikenal dengan TOEFL Institutional Testing Program (ITP).

TOEFL ITP sendiri merupakan tes yang diselenggarakan oleh lembaga Educational Testing Service (ETS) yang berdiri sejak 1947. Tes ini sering digunakan oleh institusi perguruan tinggi untuk menilai keterampilan bahasa Inggris mahasiswa untuk tujuan evaluasi, ujian akhir, dan beasiswa (ETS, 2014). Tes TOEFL ITP terdiri dari tiga bagian yaitu Listening, Structure \& Written Expression, dan Reading. Listening terdiri dari 50 nomor soal dengan waktu pengerjaan kurang lebih 35 menit; Structure \& Written Expression terdiri dari 25 nomor soal dengan waktu pengerjaan maksimal 25 menit; dan Reading terdiri dari 50 nomor soal dengan waktu pengerjaan maksimal 55 menit. Nilai tertinggi dari tes ini adalah 677 (predikat Gold atau emas) sedangkan nilai terendah adalah 310. ETS hanya menerbitkan sertifikat untuk peserta tes yang mencapai nilai minimal 460 dengan predikat Bronze (perunggu) sehingga diharapkan penutur non bahasa Inggris bisa mencapai nilai tersebut karena dianggap mencapai level Independent User (pengguna mandiri).

Namun, mencapai nilai tersebut bukan tanpa hambatan, terlebih bagi penutur non bahasa Inggris. Terdapat empat faktor utama hambatan bagi peserta tes TOEFL ITP dalam mencapai nilai yang diinginkan yaitu kurang latihan, kurang optimalnya manajemen waktu, perbedaan pelafalan antara bahasa Indonesia dan Inggris, dan kurangnya penguasaan kosa kata dalam bahasa Inggris (Lubis \& Irmayana, 2019). Upaya peningkatan nilai TOEFL sudah pernah dilakukan oleh Utami \& Pirmansyah (2018) menggunakan metode pelatihan intensif namun hasil dari kegiatan ini justru menunjukkan penurunan nilai TOEFL secara keseluruhan dikarenakan tidak semua bagian dipelajari dalam kegiatan ini, hanya bagian Structure \& Written Expression yang menjadi perhatian. Mereka menyarankan agar kegiatan serupa berikutnya bisa lebih komprehensif mengingat keterbatasan sumber daya manusia yang dihadapi saat kegiatan tersebut sedang berjalan. Hal ini menjadi salah satu alasan diadakannya pengabdian masyarakat untuk mahasiswa tingkat akhir di Politeknik Ketenagakerjaan.

Politeknik Ketenagakerjaan (disingkat Polteknaker) merupakan sebuah institusi pendidikan tinggi yang resmi berdiri pada tahun 2017 di bawah naungan Kementerian

ACITYA BHAKTI, Volume 2 Nomor 1, Februari 2022 
Ketenagakerjaan yang menyelenggarakan pendidikan vokasi (Polteknaker, 2021). Institusi ini menawarkan tiga program studi yaitu D-IV Relasi Industri (RI), D-IV Keselamatan dan Kesehatan Kerja (K3), dan D-III Manajemen Sumber Daya Manusia (MSDM). Di tahun 2021, mahasiswa angkatan pertamanya rencananya akan diwisudakan namun ternyata mereka belum dibekali dengan keterampilan TOEFL ITP dikarenakan belum optimalnya fungsi Unit Penunjang Bahasa di kampus tersebut dan belum adanya instruktur TOEFL ITP yang kompeten di kampus tersebut

Berdasarkan latar belakang tersebut, maka pelatihan TOEFL ITP diadakan bagi mahasiswa tingkat akhir Politeknik Ketenagakerjaan sebagai luaran dari kegiatan pengabdian masyarakat ini.

\section{B. Pelaksanaan dan Metode}

Kegiatan pelaksaan pengabdian kepada masyarakat ini berlangsung dari tanggal 30 Juli 2021 dan berakhir pada tanggal 16 Agustus 2021 menggunakan media zoom dikarenakan sedang pandemi COVID-19. Total pertemuan untuk pelatihan ini adalah 8 kali terdiri dari satu kali pre-test (tes awal sebelum dimulai pelatihan), 6 kali pembekalan materi, dan satu kali post-test (tes akhir setelah mengikuti seluruh rangkaian pelatihan). Durasi setiap pertemuan kurang lebih 120 menit. Peserta kegiatan merupakan mahasiswa tingkat akhir Politeknik Ketenagakerjaan dan beberapa tenaga pendidik yang belum terbiasa dengan tes TOEFL ITP. Jumlah pendaftar awal untuk kegiatan ini adalah 88 orang, namun yang mengikuti pre-test hanya 76 orang. Pada akhir pelatihan, jumlah peserta yang mengikuti post-test sebesar 39 orang.

Metode ceramah, drill dan tanya jawab digunakan dalam proses penyampaian materi dalam kegiatan pengabdian kepada masyarakat ini. Pada metode ceramah, instruktur yang adalah Calon Pegawai Negeri Sipil dengan latar belakang sebagai instruktur TOEFL menjelaskan tentang materi dalam bentuk power points kemudian memberikan contoh-contoh soal untuk dikerjakan (drill) oleh peserta. Setelah itu, diadakan sesi tanya jawab untuk memperdalam materi yang sudah diberikan.

Secara garis besar, pelaksanaan dan metode dalam kegiatan pengabdian kepada masyarakat ini mirip dengan kegiatan yang sudah pernah dilaksanakan oleh Syamsurrijal et al. (2021). Kegiatan dimulai dengan mempersiapkan instruktur dan bahan ajar untuk sistem pembelajaran daring. Kemudian, dilakukan sosialisasi kepada calon peserta lewat group WhatsApp. Setelah peserta mendaftar, dilakukan pre-test untuk melihat gambaran awal kemampuan peserta yang juga dijadikan sebagai tolak ukur untuk melihat keberhasilan kegiatan ini di akhir kegiatan (posttest). Setelah pre-test peserta dilatih dengan metode yang sudah dirancang oleh instruktur. Langkah terakhir adalah dilakukan evaluasi setelah post-test untuk melihat keberhasilan kegiatan.

\section{Hasil dan Pembahasan}

Bagian ini akan menjelaskan secara detail proses implementasi kegiatan pengabdian kepada masyarakat dan indikator keberhasilan program. 


\section{Proses Implementasi}

Kegiatan pengabdian dimulai dengan membuka pendaftaran dengan cara menyebarkan pamflet seperti di bawah ke grup WhatsApp:

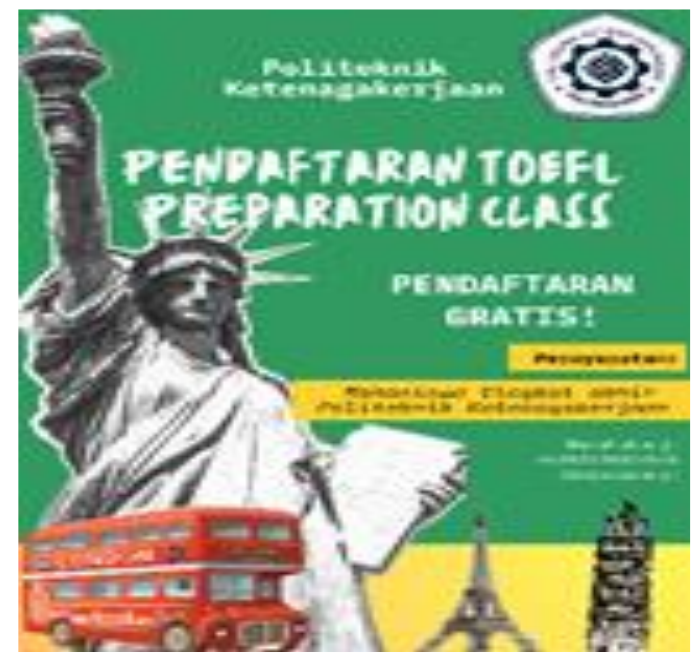

Gambar 1. Pamflet Pendaftaran Kelas TOEFL

Link pendaftaran: bit.ly/DaftarTOEFLPolteknaker

Di dalam pamflet tersebut tertera dengan jelas informasi tentang pembukaan pendafataran untuk kelas persiapan TOEFL mulai dari biaya pendaftaran sampai dengan narahubung yang bisa dihubungi untuk pendaftaran. Setelah pamflet diedarkan, calon peserta mendaftar di tautan yang terlebih dahulu sudah dibagikan di dalam grup WhatsApp.

Tabel 1. Daftar Nama Calon Peserta

\begin{tabular}{|c|l|c|c|}
\hline No & Nama Lengkap & Program Studi & Angkatan \\
\hline 1 & Melghiana Puspa Ningrum & D-III MSDM & 2017 \\
\hline 2 & Helmy Nurrahman Wibowo & D-III MSDM & 2017 \\
\hline 3 & Rifqah Rafilah & D-III MSDM & 2018 \\
\hline 4 & Muhammad Rifqi Sofyan & D-III MSDM & 2018 \\
\hline 5 & Muhammad Bima Nur Sya'bani & D-III MSDM & 2018 \\
\hline 6 & Fika Permatasari & D-III MSDM & 2018 \\
\hline 7 & Cinthya Damayanti & D-III MSDM & 2018 \\
\hline 8 & Sarah Simanungkalit & D-III MSDM & 2018 \\
\hline 9 & Mellinia Cika Kasan & D-III MSDM & 2018 \\
\hline 10 & Alfian Nuruzzaman & D-III MSDM & 2018 \\
\hline 11 & Niken Anggun Pangesti & D-III MSDM & 2018 \\
\hline 12 & Annisa Aulia Huljannah & D-III MSDM & 2018 \\
\hline 13 & Gayuh Ajeng Novita Sari & D-III MSDM & 2018 \\
\hline 14 & Fera Elviana & D-III MSDM & 2018 \\
\hline 15 & Hanna Firlyana Siregar & D-III MSDM & 2018 \\
\hline 16 & Salma Athiyyah Fajri & D-III MSDM & 2018 \\
\hline 17 & Vinanda Yusmar & D-III MSDM & 2018 \\
\hline 18 & Lady Olivia Mahardika & D-III MSDM & 2018 \\
\hline 19 & Dzakki Adam Sofyan & D-III MSDM & 2018 \\
\hline 20 & Intan Nur El Frida & D-III MSDM & 2018 \\
\hline & \multicolumn{3}{|l}{36} \\
\hline
\end{tabular}




\begin{tabular}{|c|c|c|c|}
\hline No & Nama Lengkap & Program Studi & Angkatan \\
\hline 21 & Abrar Abiyyu Ikbar & D-III MSDM & 2019 \\
\hline 22 & Kholid Barmaki & D-III MSDM & 2019 \\
\hline 23 & Sarah Rizkika Ifa Muna & D-III MSDM & 2019 \\
\hline 24 & Riski Darmawan & D-III MSDM & 2019 \\
\hline 25 & Marfuhasri Suhada & D-III MSDM & 2019 \\
\hline 26 & Raysa Hanik Alvianita & D-III MSDM & 2019 \\
\hline 27 & Marsha Shabilla Iskandar & D-III MSDM & 2019 \\
\hline 28 & Putri Amalia Alfiana & D-III MSDM & 2019 \\
\hline 29 & Nada Nazihah Dharmawan & D-III MSDM & 2019 \\
\hline 30 & Angelia Larasati & D-III MSDM & 2019 \\
\hline 31 & Meiliana Afifah & D-III MSDM & 2019 \\
\hline 32 & Intabayu Ardiyana & D-III MSDM & 2019 \\
\hline 33 & Rizcha Aliffia Sumarno & D-III MSDM & 2019 \\
\hline 34 & Renhard Daniel Siahaan & D-III MSDM & 2019 \\
\hline 35 & Devy Natalia Arianto & D-III MSDM & 2019 \\
\hline 36 & Yulian Dwi Putri Nurlaili & D-III MSDM & 2019 \\
\hline 37 & Afina Nurahma Mohamad & D-III MSDM & 2019 \\
\hline 38 & Resti Nurdianti & D-III MSDM & 2019 \\
\hline 39 & Rahma Amelia Vialin & D-III MSDM & 2019 \\
\hline 40 & Haliza Nur Fauzi & D-III MSDM & 2019 \\
\hline 41 & Takamay Jason Hermantika Irsyad & D-IV K3 & 2017 \\
\hline 42 & Iqbal Ata Dani & D-IV K3 & 2017 \\
\hline 43 & Anisa Yeni Anggraini & D-IV K3 & 2017 \\
\hline 44 & Ari Komari & D-IV K3 & 2017 \\
\hline 45 & Lucky Okta Wardaningrum & D-IV K3 & 2017 \\
\hline 46 & Mila Nur Dewianti & D-IV K3 & 2017 \\
\hline 47 & Fildzah Fatilah Rahmat & D-IV K3 & 2017 \\
\hline 48 & Russeline Vania Chrestella P & D-IV K3 & 2017 \\
\hline 49 & Hana Carisna Nur Azizah & D-IV K3 & 2017 \\
\hline 50 & Zahra Khairunnisa & D-IV K3 & 2017 \\
\hline 51 & Deyanti Eka Putri & D-IV K3 & 2017 \\
\hline 52 & Wiwin Kurniari & D-IV K3 & 2017 \\
\hline 53 & Azizah Nisya Mohamad & D-IV K3 & 2017 \\
\hline 54 & Muhammad Yanuar Ramadhan & D-IV K3 & 2017 \\
\hline 55 & Auralia Megauly Siagian & D-IV K3 & 2017 \\
\hline 56 & Dika Hanggara & D-IV K3 & 2017 \\
\hline 57 & Dwi Rahayu & D-IV K3 & 2017 \\
\hline 58 & Muhammad Fathur Rizki & D-IV K3 & 2017 \\
\hline 59 & Nurul Oktaviana & D-IV K3 & 2017 \\
\hline 60 & Elita Dewi Nopiatis & D-IV K3 & 2017 \\
\hline 61 & Rudika Yoga Kurniawan Ismail & D-IV RI & 2017 \\
\hline 62 & Filisitas Arianie Widyantara & D-IV RI & 2017 \\
\hline 63 & Muhamad Indrawan & D-IV RI & 2017 \\
\hline 64 & Adam Jatmiko & D-IV RI & 2017 \\
\hline 65 & Gagah Prakoso & D-IV RI & 2017 \\
\hline 66 & Muhamad Hafisz Kausari & D-IV RI & 2017 \\
\hline 67 & Suci Mulia Sari & D-IV RI & 2017 \\
\hline 68 & Rika Wustia Namora & D-IV RI & 2017 \\
\hline 69 & Depris Lumban Toruan & D-IV RI & 2017 \\
\hline 70 & Mutia Anggraini & D-IV RI & 2017 \\
\hline 71 & Riska Nurmalasari & D-IV RI & 2017 \\
\hline
\end{tabular}




\begin{tabular}{|c|l|c|c|}
\hline No & Nama Lengkap & Program Studi & Angkatan \\
\hline 72 & Idzni Nabilah & D-IV RI & 2017 \\
\hline 73 & Nur Afifah & D-IV RI & 2017 \\
\hline 74 & Fauzan Rahman Ogie & D-IV RI & 2017 \\
\hline 75 & Nada Octavia Purba & D-IV RI & 2017 \\
\hline 76 & Dias Anggi Lestari & D-IV RI & 2017 \\
\hline 77 & Luthfiana Islami & D-IV RI & 2017 \\
\hline 78 & Muhamad Irfan Maulana & D-IV RI & 2017 \\
\hline 79 & Nisrina Luthfi Wahyudi & D-IV RI & 2017 \\
\hline 80 & Dwi Cahyatiarso & D-IV RI & 2017 \\
\hline 81 & Idzni Nabilah & D-IV RI & 2017 \\
\hline 82 & Muhammad Yusuf Badruttamam & D-IV RI & 2017 \\
\hline 83 & Safira Azka Tazkiyatullaili & D-IV RI & 2017 \\
\hline 84 & Nandi Novanto & D-IV RI & 2017 \\
\hline 85 & Tuti Ningrum & Dosen D-III MSDM & \\
\hline 86 & Athira & Dosen D-III MSDM & \\
\hline 87 & Anis Rohmana Malik & Dosen D-IV K3 & \\
\hline 88 & Yusnita Handayani & Dosen D-IV K3 & \\
\hline
\end{tabular}

Tabel di atas merupakan data peserta yang sudah diolah yang menunjukkan total jumlah peserta awal sebanyak 88 peserta. Dari total 88 peserta tersebut, 40 peserta $(45,45 \%)$ merupakan mahasiswa program studi D-III Manajemen Sumber Daya Manusia (MSDM) dengan rincian dua mahasiswa (2,27\%) angkatan 2017, 18 mahasiswa (20,45\%) angkatan 2018, dan 20 mahasiswa (22,73) angkatan 2020. Berikutnya, mahasiswa yang mendaftar dari program D-IV Relasi Industri (RI) adalah sebanyak 24 peserta $(27,27 \%)$ yang merupakan mahasiswa angkatan 2017. Selanjutnya, jumlah mahasiswa program studi D-IV Keselamatan dan Kesehatan Kerja (K3) angkatan 2017 adalah sebanyak 20 peserta (22,73\%). Terakhir, terdapat empat dosen $(4,55 \%)$ yang mendaftar terdiri dari masing-masing dua dosen $(2,27 \%)$ program studi D-III MSDM dan program studi D-IV K3. Dari daftar rincian ini, antusiasme sivitas akademika Politeknik Ketenagakerjaan untuk mengikuti kelas pelatihan TOEFL ITP ini sangat tinggi mengingat kelas ini yang semula dikhususkan untuk mahasiwa tingkat akhir Politeknik Ketenagakerjaan (angkatan 2017 bagi ketiga program studi dan tambahan angkatan 2018 untuk program studi D-III MSDM) pada pelaksanaannya akhirnya juga membuka kesempatan bagi sivitas akademika lainnya.

\section{Indikator Keberhasilan Program}

Meskipun jumlah pendaftar awal kegiatan ini berjumlah 88, namun hanya 34 peserta $(38,64 \%)$ yang mengikuti seluruh rangkaian kegiatan ini dimulai dengan pre-test, pembekalan materi, dan post-test seperti tabel di bawah.

Tabel 2. Nilai pre-test, post-test, dan perubahan

\begin{tabular}{|c|c|c|c|c|c|c|c|c|c|}
\hline \multirow{2}{*}{$\begin{array}{c}\text { No } \\
\text {. }\end{array}$} & \multicolumn{2}{|c|}{ Listening } & \multicolumn{2}{|c|}{$\begin{array}{c}\text { Structure \& } \\
\text { Written } \\
\text { Expression }\end{array}$} & \multicolumn{2}{|c|}{ Reading } & \multicolumn{2}{|c|}{ Total Score } & \multirow{2}{*}{$\begin{array}{c}\text { Perubaha } \\
\text { n } \\
(\%)\end{array}$} \\
\hline & $\begin{array}{l}\text { Pre- } \\
\text { test }\end{array}$ & $\begin{array}{c}\text { Post- } \\
\text { test }\end{array}$ & $\begin{array}{l}\text { Pre- } \\
\text { test }\end{array}$ & $\begin{array}{c}\text { Post- } \\
\text { test }\end{array}$ & $\begin{array}{l}\text { Pre- } \\
\text { test }\end{array}$ & $\begin{array}{c}\text { Post- } \\
\text { test }\end{array}$ & $\begin{array}{c}\text { Pre- } \\
\text { test }\end{array}$ & $\begin{array}{r}\text { Post- } \\
\text { test }\end{array}$ & \\
\hline 1 & 31 & 46 & 24 & 20 & 21 & 58 & 253 & 413 & 63.24 \\
\hline
\end{tabular}

ACITYA BHAKTI, Volume 2 Nomor 1, Februari 2022 


\begin{tabular}{|c|c|c|c|c|c|c|c|c|c|}
\hline \multirow{2}{*}{$\begin{array}{c}\text { No } \\
\text {. }\end{array}$} & \multicolumn{2}{|c|}{ Listening } & \multicolumn{2}{|c|}{$\begin{array}{c}\text { Structure \& } \\
\text { Written } \\
\text { Expression }\end{array}$} & \multicolumn{2}{|c|}{ Reading } & \multicolumn{2}{|c|}{ Total Score } & \multirow{2}{*}{$\begin{array}{c}\text { Perubaha } \\
\text { n } \\
(\%)\end{array}$} \\
\hline & $\begin{array}{l}\text { Pre- } \\
\text { test }\end{array}$ & $\begin{array}{c}\text { Post- } \\
\text { test }\end{array}$ & $\begin{array}{l}\text { Pre- } \\
\text { test }\end{array}$ & $\begin{array}{c}\text { Post- } \\
\text { test }\end{array}$ & $\begin{array}{c}\text { Pre- } \\
\text { test }\end{array}$ & $\begin{array}{c}\text { Post- } \\
\text { test }\end{array}$ & $\begin{array}{l}\text { Pre- } \\
\text { test }\end{array}$ & $\begin{array}{c}\text { Post- } \\
\text { test }\end{array}$ & \\
\hline 2 & 24 & 52 & 24 & 47 & 55 & 52 & 343 & 503 & 46.64 \\
\hline 3 & 24 & 39 & 37 & 37 & 21 & 40 & 273 & 387 & 41.75 \\
\hline 4 & 24 & 44 & 31 & 31 & 28 & 38 & 276 & 377 & 36.59 \\
\hline 5 & 24 & 49 & 39 & 46 & 52 & 48 & 383 & 477 & 24.54 \\
\hline 6 & 49 & 56 & 48 & 63 & 53 & 61 & 500 & 600 & 20 \\
\hline 7 & 56 & 65 & 49 & 60 & 55 & 63 & 533 & 627 & 17.63 \\
\hline 8 & 38 & 62 & 49 & 41 & 47 & 52 & 446 & 517 & 15.91 \\
\hline 9 & 33 & 51 & 45 & 43 & 50 & 53 & 426 & 490 & 15.02 \\
\hline 10 & 43 & 47 & 38 & 45 & 45 & 52 & 420 & 480 & 14.28 \\
\hline 11 & 52 & 52 & 38 & 45 & 49 & 58 & 463 & 517 & 11.66 \\
\hline 12 & 43 & 51 & 51 & 60 & 59 & 59 & 510 & 567 & 11.17 \\
\hline 13 & 35 & 41 & 38 & 36 & 41 & 49 & 380 & 420 & 10.52 \\
\hline 14 & 49 & 52 & 41 & 47 & 44 & 47 & 446 & 487 & 9.19 \\
\hline 15 & 49 & 54 & 42 & 51 & 54 & 52 & 483 & 523 & 8.28 \\
\hline 16 & 49 & 51 & 43 & 48 & 47 & 49 & 463 & 493 & 6.47 \\
\hline 17 & 41 & 49 & 44 & 41 & 47 & 49 & 440 & 463 & 5.22 \\
\hline 18 & 49 & 55 & 43 & 41 & 52 & 51 & 480 & 490 & 2.08 \\
\hline 19 & 49 & 49 & 45 & 49 & 47 & 45 & 470 & 477 & 1.48 \\
\hline 20 & 54 & 54 & 38 & 41 & 48 & 46 & 466 & 470 & 0.85 \\
\hline 21 & 48 & 45 & 43 & 44 & 48 & 48 & 463 & 457 & -1.29 \\
\hline 22 & 54 & 51 & 41 & 42 & 44 & 44 & 463 & 457 & -1.29 \\
\hline 23 & 38 & 33 & 32 & 35 & 46 & 46 & 386 & 380 & -1.55 \\
\hline 24 & 53 & 49 & 47 & 45 & 47 & 49 & 490 & 477 & -2.65 \\
\hline 25 & 52 & 56 & 51 & 45 & 54 & 50 & 523 & 503 & -3.82 \\
\hline 26 & 51 & 51 & 48 & 46 & 52 & 48 & 503 & 483 & -3.97 \\
\hline 27 & 45 & 51 & 50 & 46 & 65 & 56 & 533 & 510 & -4.31 \\
\hline 28 & 37 & 24 & 32 & 42 & 39 & 36 & 360 & 340 & -5.55 \\
\hline 29 & 53 & 51 & 48 & 40 & 48 & 46 & 496 & 457 & -7.86 \\
\hline 30 & 38 & 24 & 38 & 40 & 46 & 43 & 406 & 357 & -12.06 \\
\hline 31 & 24 & 24 & 44 & 20 & 42 & 51 & 366 & 317 & -13.38 \\
\hline 32 & 41 & 24 & 41 & 37 & 44 & 47 & 420 & 360 & -14.28 \\
\hline 33 & 35 & 41 & 45 & 20 & 39 & 40 & 396 & 337 & -14.89 \\
\hline 34 & 24 & 24 & 35 & 44 & 46 & 21 & 350 & 297 & -15.14 \\
\hline
\end{tabular}

Secara keseluruhan, terjadi peningkatan nilai sebesar 6,16\% dengan rincian 20 peserta mengalami kenaikan sedangkan 14 peserta mengalami penurunan dari hasil pre-test ke post-test. Dari total 34 peserta yang mengikuti pelatihan, 20 peserta berhasil mendapatkan nilai total minimal sebesar 460 (peringkat Bronze) pada posttest, dari yang sebelumnya hanya 16 peserta saat pre-test. Hal ini menunjukkan bahwa pemaparan materi menggunakan media zoom, seperti pada gambar di bawah ini, dapat dikatakan cukup berhasil meski tidak terlalu signifikan terhadap peserta pelatihan. 

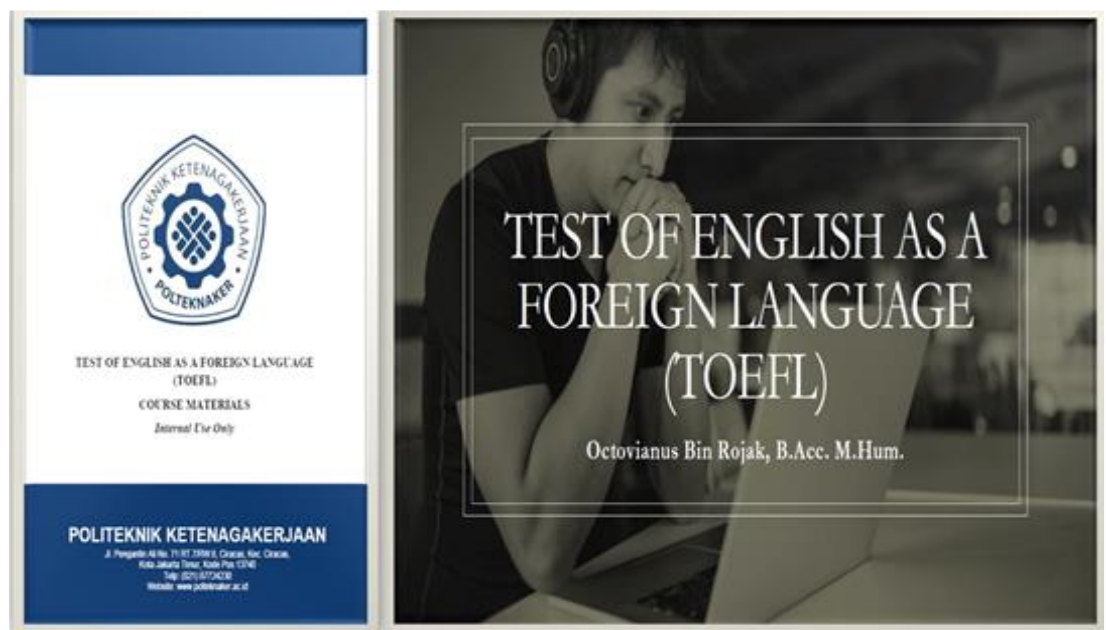

Gambar 2. Materi pelatihan berupa

dokumen portable document format (.pdf) dan powerpoint (.ppt)

Sebelum kelas secara dalam jaringan dimulai, peserta dikirimkan materi berupa dokumen .pdf dan .ppt seperti di dalam Gambar 2.

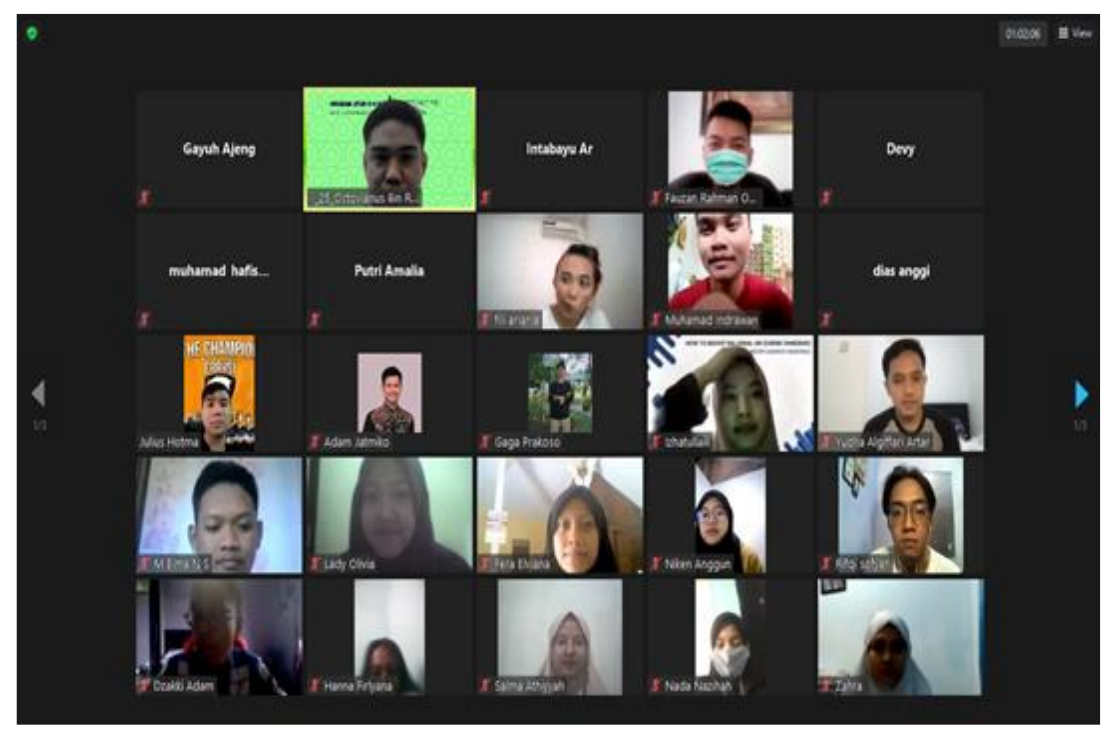

Gambar 3. Pembekalan materi menggunakan media zoom

Kemudian, saat berada di dalam kelas materi .ppt akan dipaparkan, dilanjutkan dengan drill (latihan soal), kemudian terakhir, sesi tanya jawab seperti di dalam Gambar 3.

\section{Penutup}

Bagian ini akan menjelaskan kesimpulan dan saran dari kegiatan pengabdian kepada masyarakat ini. Selain itu, penulis juga menyampaikan ucapan terima kasihnya kepada pihak-pihak yang sudah terlibat di dalam kegiatan pelaksanaan ini.

ACITYA BHAKTI, Volume 2 Nomor 1, Februari 2022 


\section{Simpulan}

Kegiatan pengabdian kepada masyarakat dengan luaran pelatihan TOEFL ITP untuk mahasiswa tingkat akhir di Politeknik Ketenagakerjaan ini dianggap sukses mencapai tujuannya dibuktikan dengan terjadi peningkatan nilai tes awal dan akhir peserta sebesar $6,16 \%$. Namun, kegiatan ini bukan tanpa hambatan sama sekali.

Setidaknya terdapat dua faktor penghambat pelaksanaan kegiatan ini yaitu pelaksanaannya yang bersifat dalam jaringan dan ketidaksesuaian antara jadwal yang tersedia antara peserta dengan jadwal pelatihan. Di era pandemi COVID-19, semua pihak harus beradaptasi dengan kebiasaan baru termasuk dunia pendidikan. Kegiatan belajar mengajar (KBM) beralih 100\% dari tatap muka langsung ke pembelajaran dalam jaringan. Namun, belum semua pihak siap beradaptasi dengan kebiasaan ini, termasuk peserta pelatihan TOEFL ITP di dalam kegiatan ini. Hal yang paling lumrah terjadi adalah konsentrasi peserta mudah pecah dikarenakan terlalu banyak distraksi entah itu dari kendala jaringan maupun kendala perangkat yang digunakan. Berikutnya, ketidaksesuaian terjadi antara jadwal peserta dengan jadwal pelatihan dikarenakan rata-rata peserta merupakan mahasiswa yang sedang melaksanakan program kerja lapangan (PKL) di perusahaan-perusahaan sehingga ada beberapa yang melewatkan beberapa pertemuan, bahkan tidak mengikuti pelatihan sampai dengan akhir.

\section{Saran}

Meskipun dianggap mencapai tujuannya, masih ada ruang untuk perbaikan dari kegiatan ini. Pertama, durasi pelatihan TOEFL ITP ini seharusnya dibuat menjadi lebih panjang yang berarti jumlah pertemuannya ditambah. Hal ini sangat dibutuhkan oleh peserta yang daya tangkapnya masih di bawah rata-rata dibandingkan dengan peserta yang lain. Kedua, kelas harus dibuat terpisah antara peserta dengan kemampuan rata-rata, di atas rata-rata, dan di bawah rata-rata sehingga instruktur lebih bisa menyesuaikan pola mengajar ke peserta-pesertanya. Ketiga, penyusunan jadwal disusun sesuai dengan ketersediaan pesertanya sehingga mereka bisa selalu mengikuti kelas secara langsung. Terakhir, materi yang sudah diajarkan diunggah ke media seperti YouTube supaya peserta tetap bisa mengaksesnya untuk pembelajaran pribadi.

\section{Ucapan Terima Kasih}

Penulis mengucapkan terima kasih kepada Plt. Direktur Politeknik Ketenagakerjaan, Bapak Elviandi RS., S.E., M.Hum., Ph.D., karena mengizinkan penulis melaksanakan kegiatan pengabdian kepada masyarakat ini di kampus Politeknik Ketenagakerjaan. Selain itu, penulis juga mengucapkan terima kasih kepada Plt. Pembantu Direktur I - Bidang Akademik, Ibu Ida Umarul Mufidah, S.T., M.Si., yang sudah sangat kooperatif membantu menyebarkan informasi terkait pembukaan pelatihan ini kepada mahasiswa-mahasiswa dan beberapa tenaga pendidik di Politeknik Ketenagakerjaan, sekaligus memberikan izin kepada penulis untuk melaksanakan kegiatan ini. 


\section{DAFTAR PUSTAKA}

ETS. (2014). Official guide to the TOEFL ITP Test. ETS.

Fitria, T. N., \& Prastiwi, I. E. (2020). Pelatihan tes TOEFL (Test of English Foreign Language) untuk siswa SMK/SMA, mahasiswa, dosen, dan umum. Jurnal Budimas, 02(02), 43-49.

Lubis, L. R., \& Irmayana, A. (2019). Analisis Kesulitan Mahasiswa IPTS dalam Menyelesaikan Soal-Soal TOEFL. Jurnal Education and Development, 7(3), 118. https://doi.org/10.37081/ed.v7i3.1202

Polteknaker. (2021). Sejarah Kampus. https://polteknaker.ac.id/sejarah-kampus/

Salam, U. (2017). Toefl Antara Penting Dan Frustasi: Analisis Kebijakan "Toefl” Di Universitas Tanjungpura. Journal of Prospective Learning, 2(1), 37-44.

Syamsurrijal, S., Ceriyani Miswaty, T., \& Pahrul Hadi, M. Z. (2021). Pelatihan TOEFL dengan Metode Cooperative Integrated Reading and Composition untuk Mencapai Nilai Ideal di Masa Pandemi. Jurnal Pengabdian Masyarakat Indonesia, 1(5), 217-226. https://doi.org/10.52436/1.jpmi.48

Utami, S. S., \& Pirmansyah, B. (2018). Peningkatan Skor Test Bahasa Inggris (TOEFL) melalui Pelatihan secara Intensif. Lingua Franca:Jurnal Bahasa, Sastra, Dan Pengajarannya, 2(2), 36. https://doi.org/10.30651/lf.v2i2.1477 